\title{
Synergistic Effect of Low Doses of X-rays and Biobras-16 on Yield and Its Components in Tomato (Solanum lycopersicum L.) Plants
}

\author{
Yanelis Camejo Serrano ${ }^{1}$, Ramiro Ramírez Fernández ${ }^{1}$, Franklin Rivera Pineda ${ }^{2}$, \\ Lilita T. Sueiro Pelegrin ${ }^{1}$, Dagoberto García Fernández ${ }^{1}$, María Caridad González Cepero ${ }^{3}$ \\ ${ }^{1}$ Direction of environmental research , Agricultural Research Institute "Jorge Dimitrov", Bayamo, Granma, Cuba \\ ${ }^{2}$ Division of Sustainable Development, Intercultural University of Mexico State, San Felipe, Mexico State, Mexico \\ ${ }^{3}$ Department of Genetic, National Institute of Agricultural Sciences, San José de las Lajas, Mayabeque, Cuba
}

Email address:

ycamejo@dimitrov.cu (Y. C. Serrano), rramirez@dimitrov.cu (R. R. Fernández), biofranklin@yahoo.com (F. R. Pineda)

To cite this article:

Yanelis Camejo Serrano, Ramiro Ramírez Fernández, Franklin Rivera Pineda, Lilita T. Sueiro Pelegrin, Dagoberto García Fernández, María Caridad González Cepero. Synergistic Effect of Low Doses of X-rays and Biobras-16 on Yield and Its Components in Tomato (Solanum lycopersicum L.) Plants. American Journal of Bioscience and Bioengineering. Vol. 3, No. 6, 2015, pp. 197-202.

doi: $10.11648 /$ j.bio.20150306.18

\begin{abstract}
In Cuba the low tomato crop yield lead to the search for new alternatives to sustainably increase yields. Therefore, the aim of this study was to evaluate the synergistic effect of low doses of X-rays and Biobras-16 on the increased yield and its components in tomato plants as well as select the optimal combination for use in agriculture. Fresh seeds of the variety of tomato var. Vyta, were exposed to single and combined treatment with X-ray dose of 5, 10, 15, 20 and 25 Gy and Biobras-16 in concentrations of $0.5 ; 1.0 ; 1.5$ and $2.0 \mathrm{mg} . \mathrm{L}^{-1}$. The experiments were conducted during the months of October to January 2007-2010. The results showed that the combination of 20 and $25 \mathrm{~Gy}$ dose of X-rays and 1.5 and $2.0 \mathrm{mg} . \mathrm{L}^{-1}$ Biobras-16 caused a stimulating effect on yield and its components in tomato plants. Also, in this investigation was determined that the optimal treatment to achieve a synergistic effect on yield per plant was $30 \mathrm{~Gy}+2.0 \mathrm{mg} \cdot \mathrm{L}^{-1}$, which induced increases in yield and its components. Our results suggested that low doses of x-rays and Biobras- 16 have the potential to improve crop productivity of tomato plants through the improvement of plant yield and yield components.
\end{abstract}

Keywords: Radiation, Radiostimulation, Brasinoesteroids

\section{Introduction}

Studies about the action of ionizing radiation on the plant organism began in 1895 with the discovery of X-rays, which conferred upon W. Conrad Roentgen's first Nobel Prize in physics. The discovery of this new type of radiation led to the international scientific community to the development of numerous investigations related to their biological effects in living organisms [1].

Research carried out until today, have confirmed the stimulating effect of low doses of X-rays in many species of plants, also corroborated that their effectiveness depends not only on the integral dose of radiation absorbed by the vegetal organism, but also a series of interrelated biological or environmental factors that can enhance or diminish this stimulatory effect [2].
This marked susceptibility of the stimulating effect of different types of factors suggested to study the response of plants to the combination of ionizing radiation with some plant hormones; corroborating a synergistic response of auxins, gibberellins, cytokinins, abscisic acid and ethylene with low doses of X-rays [3], reversing a great importance from the theoretical and practical point of view.

From this investigations in the Agricultural Research Institute "Jorge Dimitrov", with a wide experience in the application of stimulants physical methods was initiated a new research project in order to study the synergistic effect of low doses of X-rays and brassinosteroids on some agronomic indicators in tomato plants.

Brassinosteroids are considered the sixth class of plant hormone. They are natural substances with pleiotropic effects in plants, promoting growth at very low concentrations, for stimulation of cell elongation and regeneration of the cell wall 
leading to increased biomass and yield $[4,5]$.

In Cuba, since the early nineties, that has been reported the biological activity and the practical applications of similar spirostanics of brassinosteroid. Consequently, there are many reports of Biobras- 6 and Biobras-16, which have been used successfully in practical applications in agriculture [6].

The objective of this study was to evaluate the combined effect of low doses of X-rays and Biobras-16 on yield and its components of tomato plants of the variety Vyta and to select the optimal stimulants doses.

\section{Materials and Methods}

The research was carried out at an intensive orchard located in Bayamo, Cuba during the years 2007-2010, from October to January, corresponding to the optimal period for vegetable production. Tomato seeds of variety Vyta were selected and exposed to low doses of X-rays (Table 1) in the morning, with a temperature of $24 \pm 1^{\circ} \mathrm{C}$ and $12-14 \%$ homogenized seed moisture content. In the irradiative treatment an X-ray source of Philips trade mark with an aluminum filter of $0.75 \mathrm{~mm}$ and a work regime of $55 \mathrm{KV}$ and $30 \mathrm{~mA}$ and a power of $11.47 \mathrm{~Gy}$ dose / min was used.

Table 1. Treatments applied with X-rays and Biobras-16.

\begin{tabular}{|c|c|c|c|c|c|}
\hline Treatments & $\begin{array}{l}\text { Radiation } \\
\text { dose (Gy) }\end{array}$ & $\begin{array}{l}\text { BB -16 } \\
\left(\mathrm{mg} \cdot \mathrm{L}^{-1}\right)\end{array}$ & Treatments & $\begin{array}{l}\text { Radiation } \\
\text { dose (Gy) }\end{array}$ & $\begin{array}{l}\text { BB -16 } \\
\left(\mathrm{mg} . \mathrm{L}^{-1}\right)\end{array}$ \\
\hline Control & 0 & 0 & $\mathrm{~T}_{15}$ & 15 & 0 \\
\hline $\mathrm{T}_{1}$ & 0 & 0.5 & $\mathrm{~T}_{16}$ & 15 & 0.5 \\
\hline $\mathrm{T}_{2}$ & 0 & 1.0 & $\mathrm{~T}_{17}$ & 15 & 1.0 \\
\hline $\mathrm{T}_{3}$ & 0 & 1.5 & $\mathrm{~T}_{18}$ & 15 & 1.5 \\
\hline $\mathrm{T}_{4}$ & 0 & 2.0 & $\mathrm{~T}_{19}$ & 15 & 2.0 \\
\hline $\mathrm{T}_{5}$ & 5 & 0 & $\mathrm{~T}_{20}$ & 20 & 0 \\
\hline $\mathrm{T}_{6}$ & 5 & 0.5 & $\mathrm{~T}_{21}$ & 20 & 0.5 \\
\hline $\mathrm{T}_{7}$ & 5 & 1.0 & $\mathrm{~T}_{22}$ & 20 & 1.0 \\
\hline $\mathrm{T}_{8}$ & 5 & 1.5 & $\mathrm{~T}_{23}$ & 20 & 1.5 \\
\hline $\mathrm{T}_{9}$ & 5 & 2.0 & $\mathrm{~T}_{24}$ & 20 & 2.0 \\
\hline $\mathrm{T}_{10}$ & 10 & 0 & $\mathrm{~T}_{25}$ & 25 & 0 \\
\hline $\mathrm{T}_{11}$ & 10 & 0.5 & $\mathrm{~T}_{26}$ & 25 & 0.5 \\
\hline $\mathrm{T}_{12}$ & 10 & 1.0 & $\mathrm{~T}_{27}$ & 25 & 1.0 \\
\hline $\mathrm{T}_{13}$ & 10 & 1.5 & $\mathrm{~T}_{28}$ & 25 & 1.5 \\
\hline $\mathrm{T}_{14}$ & 10 & 2.0 & $\mathrm{~T}_{29}$ & 25 & 2.0 \\
\hline
\end{tabular}

Biobras-16 concentrations and low-dose X-rays and the combinations were adjusted to previous studies

The irradiated seeds were sown earlier than 48 hours after treatment. The seedlings were sown in experimental plots, with a substrate composed of a Vertisol soil [7] with an organic matter content and Litonita in a rate of 3: 1: 1 . At 20 days, the transplant was performed in rows of $1.5 \mathrm{~m}$ wide and $50 \mathrm{~m}$ long. Crop management is strictly performed following the standard agricultural practices established for tomato crops by the Ministry of Agriculture, Intensive orchards and semiprotected orchard [8], arranged to a randomized block design with four replicates per treatment.

During the blooming period (15 days after transplantation) at different concentrations of Biobras-16 (BB-16) were applied (Table 1) in a rate of $2 \mathrm{~mL}$ per plant. The leaves were sprayed during the early morning hours until they were completely wet. 16 liter backpack with conical spray nozzle was used previously calibrated.

The following parameters were evaluated: number of truss per plant (NTP), number of fruits per truss (NFT), and the mean fruit weight (MFW) and yield per plant (YPP).

Data from experiments with X-rays and BB-16, applied independently were statistically analyzed by an analysis of variance of two way classification. Means were compared using Tukey's test for a probability error of $5 \%(p \leq 0.05)$. The Kolmogorov-Smirnov procedure was used to test data normality; Bartlett's test was used to test homogeneity of variances among treatments [9]. All of the statistical analyses were performed using the "Statistica" software package, version 10 (Stat-Soft, Tulsa, OK).

Tomato yield and components data of combination treatments were calculated using the means and standard errors for each experimental variant study and processed by a bivariate analysis of variance, using as factors change dose applied X-rays and different concentrations of BB-16. Means were compared using the Newman Keuls test, for a probability of error of 5\%. An analysis of response surface was also used to determine the optimum values of the combinations of the $\mathrm{X}$-ray dose and the concentrations of BB-16 further increased yield per plant.

\section{Results and Discussion}

Tomato yield and its components of the variety Vyta were significantly increased $(\mathrm{p} \leq 0.05)$, showing the stimulating effect of low dose x-rays (Table 2). The best finding was found for T20 and T25 treatments, stimulating significantly the yield per plant and all its components, although T15 showed no significant difference with these treatments.

The number of fruits per truss (NFT) increased significantly $(p \leq 0.05)$, except $\mathrm{T} 5$ treatment, which showed no difference compared to the control. The greatest response in the indicator (8.15 fruits per truss) was observed in treatment T25, which corresponds to the dose of $25 \mathrm{~Gy}$.

The indicator number of truss per plant (NTP) only significant differences were found $(\mathrm{p} \leq 0.05)$ with respect to control, the T20 and T25 (20 to $25 \mathrm{~Gy}$ ) treatments, with values of 4.03 and 3.92 truss per plant, respectively, while the mean fruit weight (MFW) was significantly stimulated with T5, T20 and $\mathrm{T} 25$ treatments.

The yield per plant (YPP) was significantly higher than the control $(\mathrm{p} \leq 0.05)$ for T15, T20 and T25 treatments $(15,20$ and $25 \mathrm{~Gy}$ ) increased in $1.81,2.02,2.03 \mathrm{Kg}$, respectively.

Some authors [10] show similar increases in Chikpea, with the application of doses below $25 \mathrm{~Gy}$, under different growing conditions. On the other hand reported yield stimulation in carrot between $10-35 \%$ and the presence of significant stimulatory effect on forest species, to treat the seeds before they are planted with low doses of gamma rays from a Co 60 source $[11,12]$.

Alvarez $[13,14]$ indicates significant increases in the yield of hybrid tomato, the effect of seed treatment with laser 
radiation of low power.

By the other hand, [15] reported that physical methods induced biochemical changes in treated seeds, which subsequently lead to stimulating effects during growth, with a direct impact on plant yield.

Despite not having found the stimulating effect on all radiation treatments, significant increases observed corroborate the potential of use low doses of X-rays in stimulating yield and its components in plants; and the stochastic nature manifested in the response of plants from irradiated seeds.

The application of BB-16 at the first stage of flowering caused a significant stimulating effect with some treatments applied on yield and its components (Table 2).

Table 2. Combined effect of low doses of X-rays and Biobras-16 on tomato plant yield and its components.

\begin{tabular}{|c|c|c|c|c|c|c|}
\hline No. & $\begin{array}{l}\text { Radiation } \\
\text { dose (Gy) }\end{array}$ & $\begin{array}{l}\text { BB -16 } \\
\left(m g . L^{-1}\right)\end{array}$ & NFR & NRP & MFW (g) & $\begin{array}{l}\text { RPP } \\
(\mathrm{Kg})\end{array}$ \\
\hline T0 & 0 & 0 & $6.45^{\mathrm{jk}}$ & $3.60^{\mathrm{fg}}$ & $62.92^{\mathrm{kl}}$ & $1.49^{\circ}$ \\
\hline $\mathrm{T} 1$ & 0 & 5 & $6.88^{\text {hijk }}$ & $2.83^{\mathrm{i}}$ & $64.56^{\mathrm{jkl}}$ & $1.73^{\mathrm{klmno}}$ \\
\hline $\mathrm{T} 2$ & 0 & 1.0 & $7.32^{\text {efghi }}$ & $4.00^{\text {bcdefg }}$ & $68.00^{\text {ghijk }}$ & $1.99^{\text {ghijkl }}$ \\
\hline T3 & 0 & 1.5 & $7.25^{\text {efghi }}$ & $3.75^{\text {defg }}$ & $63.05^{\mathrm{kl}}$ & $1.71^{\mathrm{lmno}}$ \\
\hline $\mathrm{T} 4$ & 0 & 2.0 & $7.22^{\text {fghi }}$ & $3.85^{\text {cdefg }}$ & $69.11^{\text {efghijk }}$ & $1.92^{\mathrm{ijklm}}$ \\
\hline T5 & 5 & 0 & $6.25^{\mathrm{k}}$ & $3.55^{\mathrm{h}}$ & $77.32^{\mathrm{abcd}}$ & $1.71^{\mathrm{lmno}}$ \\
\hline T6 & 5 & 5 & $7.95^{\text {bcdefg }}$ & $3.58^{\mathrm{g}}$ & $82.02^{\mathrm{ab}}$ & $2.33^{\text {cdef }}$ \\
\hline $\mathrm{T} 7$ & 5 & 1.0 & $7.22^{\text {fghi }}$ & $3.58^{\mathrm{g}}$ & $78.11^{\mathrm{abcd}}$ & $2.02^{\text {ghijk }}$ \\
\hline T8 & 5 & 1.5 & $6.30^{\mathrm{k}}$ & $3.70^{\text {defg }}$ & $83.04^{\mathrm{a}}$ & $1.93^{\mathrm{ijklm}}$ \\
\hline T9 & 5 & 2.0 & $8.15^{\mathrm{abcd}}$ & $4.38^{\mathrm{ab}}$ & $73.22^{\text {cdefghi }}$ & $2.61^{\mathrm{abc}}$ \\
\hline $\mathrm{T} 10$ & 10 & 0 & $7.15^{\text {ghij }}$ & $3.55^{\mathrm{h}}$ & $61.55^{\mathrm{kl}}$ & $1.56^{\mathrm{no}}$ \\
\hline $\mathrm{T} 11$ & 10 & 5 & $6.70^{\mathrm{ijk}}$ & $3.80^{\text {cdefg }}$ & $59.10^{1}$ & $1.50^{\mathrm{no}}$ \\
\hline $\mathrm{T} 12$ & 10 & 1.0 & $7.15^{\text {ghij }}$ & $4.13^{\mathrm{bcd}}$ & $65.33^{\mathrm{ijkl}}$ & $1.92^{\mathrm{ijklm}}$ \\
\hline $\mathrm{T} 13$ & 10 & 1.5 & $6.90^{\mathrm{hijk}}$ & $3.90^{\text {cdefg }}$ & $65.11^{\mathrm{jkl}}$ & $1.65^{\mathrm{mno}}$ \\
\hline $\mathrm{T} 14$ & 10 & 2.0 & $7.30^{\text {efghi }}$ & $3.98^{\text {bcdefg }}$ & $67.21^{\text {hijk }}$ & $1.95^{\mathrm{hijklm}}$ \\
\hline T15 & 15 & 0 & $6.97^{\text {hijk }}$ & $3.65^{\mathrm{fg}}$ & $68.62^{\text {fghijk }}$ & $1.81^{\mathrm{jklmn}}$ \\
\hline T16 & 15 & 5 & $7.55^{\text {defgh }}$ & $4.2^{\mathrm{bc}}$ & $71.13^{\text {defghij }}$ & $2.25^{\mathrm{efgh}}$ \\
\hline T17 & 15 & 1.0 & $7.63^{\text {defgh }}$ & $3.98^{\text {bcdefg }}$ & $68.14^{\text {ghijk }}$ & $2.06^{\text {fghij }}$ \\
\hline T18 & 15 & 1.5 & $7.83^{\text {cdefg }}$ & $4.75^{\mathrm{a}}$ & $66.14^{\mathrm{ijkl}}$ & $2.45^{\text {cde }}$ \\
\hline T19 & 15 & 2.0 & $7.72^{\text {defg }}$ & $3.93^{\text {cdefg }}$ & $71.13^{\text {defghij }}$ & $2.15^{\text {fghi }}$ \\
\hline T20 & 20 & 0 & $7.65^{\text {defgh }}$ & $4.03^{\text {bcdef }}$ & $79.14^{\mathrm{abc}}$ & $2.02^{\text {ghijk }}$ \\
\hline $\mathrm{T} 21$ & 20 & 5 & $7.58^{\text {defgh }}$ & $3.95^{\text {bcdefg }}$ & $76.21^{\text {abcdef }}$ & $2.28^{\mathrm{defg}}$ \\
\hline $\mathrm{T} 22$ & 20 & 1.0 & $7.85^{\text {cdefg }}$ & $3.88^{\text {cdefg }}$ & $77.11^{\text {abcde }}$ & $2.34^{\text {cdef }}$ \\
\hline $\mathrm{T} 23$ & 20 & 1.5 & $8.60^{\mathrm{abc}}$ & $4.12^{\text {bcde }}$ & $78.95^{\text {abcd }}$ & $2.79^{\mathrm{ab}}$ \\
\hline $\mathrm{T} 24$ & 20 & 2.0 & $8.65^{\mathrm{ab}}$ & $4.22^{\mathrm{bc}}$ & $79.22^{\mathrm{abc}}$ & $2.89^{\mathrm{a}}$ \\
\hline $\mathrm{T} 25$ & 25 & 0 & $8.15^{\mathrm{abcd}}$ & $3.92^{\text {cdefg }}$ & $75.32^{\text {abcdefg }}$ & $2.03^{\text {fghijk }}$ \\
\hline $\mathrm{T} 26$ & 25 & 5 & $8.05^{\text {bcde }}$ & $3.68^{\text {efg }}$ & $79.01^{\mathrm{abcd}}$ & $2.29^{\text {cdefg }}$ \\
\hline $\mathrm{T} 27$ & 25 & 1.0 & $7.97^{\text {bcdef }}$ & $3.63^{\mathrm{fg}}$ & $75.03 b^{\text {cdefgh }}$ & $2.17^{\text {efghi }}$ \\
\hline T28 & 25 & 1.5 & $8.93^{\mathrm{a}}$ & $3.98^{\text {bcdefg }}$ & $78.25^{\mathrm{abcd}}$ & $2.78^{\mathrm{ab}}$ \\
\hline T29 & 25 & 2.0 & $8.72^{\mathrm{ab}}$ & $3.92^{\text {cdefg }}$ & $75.26^{\text {abcdefg }}$ & $2.57^{\mathrm{bcd}}$ \\
\hline$\pm \mathrm{SE}$ & & & 0.40 & 0.22 & 4.00 & 0.15 \\
\hline
\end{tabular}

In columns, means followed by different letters indicate significant differences between treatments $\mathrm{p} \leq 0.05$ by Tukey's test. SE: standard error of the mean. NFT - number of fruits per truss. NTP- number of truss per plant. MFW mean fruit weight. YPP- yield per plant.

The remarkably stimulant response $(\mathrm{p} \leq 0.05)$ was observed for the number of fruits per truss indicator (NFT), with all concentrations applied. This indicator shows increases for 1.0, 1.5 and $2.0 \mathrm{mg} . \mathrm{L}^{-1} \mathrm{BB}-16$. However, the number of truss per plant (NTP) and the mean fruit weight (MFW) showed only significant differences $(p<0.05)$ with treatments $\mathrm{T} 1 \quad(0.5$ mg. $\left.\mathrm{L}^{-1}\right)$ in the first indicator and T4 $\left(2.0 \mathrm{mg} . \mathrm{L}^{-1}\right)$ in the second. The yield per plant (YPP) increased significantly $(\mathrm{p} \leq 0.05)$ with T2 (1.0 mg.L $\left.\mathrm{L}^{-1}\right)$ and T4 (2.0 mg. $\left.\mathrm{L}^{-1}\right)$ treatment, the latter was the one who coincidentally showed significant increases in indicators NFT and MFW.

The significant increases corroborate the potentialities of the BB- 16 in stimulating yield and its components in crop plants.

The increase in the number of truss and flowers per plant in tomato crop variety "Amalia" was observed, applying BB-16, with values of 12.37 and 11.32 , respectively [16].

Also [17] reported a positive influence of BB-16 in yield of tomato plants cv. Campbell. It confirmed its influence in the increase of fresh mass, plant height and crop yield. Significant increases in yield and its components in the tomato variety Vyta, to sprinkle Biobras-16 at doses of $0.01 \mathrm{mg} . \mathrm{L}^{-1}$, in a typical floor Fluvisol medium fertility was reported [18].

In other crops, [19] found a significant increase in the length and width of tobacco leaves and agricultural yield using the folial application for different doses of BB-16.

Numerous authors, showed increases in the yield corn hybrids by applying an analogue of brassinosteroid (CIDEF4 on trilinear fertile genotypes. The highest values were achieved in this indicator of $8.083 \mathrm{t} \mathrm{ha}^{-1}$, relative to the control (3.858 $\left.\mathrm{tha}^{-1}\right)$ and the effective dose was $30 \mathrm{~g} \mathrm{ha}^{-1}$. [20].

Recent genetic studies have identified some of the molecular components located in the signaling cascade of brassinosteroids. On this basis, working in the model signaling cascade proposes an activation of the receptor complex consists of two protein kinases membrane and through its heterodimerization inhibit a third cytoplasmic kinase GSK3 type, enabling accumulation in the core of two separate proteins that are directly and indirectly related to the activation of gene expression response to brassinosteroids, something that could explain the mechanism of action of these compounds $[21,22]$.

The expression of genes coding for photosynthetic proteins could also be either direct or indirect target of BR signaling pathway. BRs mostly down-regulate the expression of genes coding for various photosynthetic proteins [23, 24, 25]. The expression of two GOLDEN 2-LIKE transcription factors (GLK1 and GLK2) which regulate production of nuclear-encoded photosynthetic proteins is inhibited by BRASSINAZOLE RESISTANT1 (BRZ1) and/or PHYTOCHROME-INTERACTING FACTOR4 (PIF4) transcription factors, other essential components of BR-signaling pathway [26].

Another important aspect that focuses the attention of some researchers of this mechanism is the fact that it has the dual function of brassinosteroid receptor in tomato (tBRI1), which also acts as a receptor for systemin hormone with a different structure and function BR competitors [27].

Brassinosteroids act on plant growth by means of cell division and elongation, which requires coordination of numerous processes. It has recently been discovered in Arabidopsis seedlings that BRI one can rapidly induce the 
expansion of the cell wall in response to brassinosteroids as brassinolide, the expansion of the wall is accompanied by rapid hyperpolarization of membrane potential, which depends on activation of the $\mathrm{H}+$-ATPase-type P. This activation requires the kinase activity of BRI 1 and appears to be mediated by an association with the receptor modulated proton pump brassinolide [28]. Moreover, it has been shown that brassinosteroids can regulate the biosynthesis of cellulose by controlling the expression of the Arabidopsis CESA [29] genes

Another way in which brassinosteroids can favor the growth is the increased expression of BRU1, TCH4, LeBR1, OsXTR1 and OsXTR3 genes, which code for XET XTH or (xyloglucan endotrans-glycosylases / hydrolases) soybean, Arabidopsis, tomato and rice, respectively [30]. The XET $\mathrm{XTH}$ or are enzymes involved in the biosynthesis and modification of the cell wall.

The bivariate factor analysis of yield per plant and its components performed showed significant interaction $(\mathrm{p} \leq$ 0.05 ) between doses of X-rays and BB-16 concentrations investigated (Table 2), indicating the existence of a synergistic effect of certain dose combinations with the use of these stimulating method.

The NFT showed the highest values of stimulation by T9, T23, T24, T25, T28 and T29 treatments; with the exception of $\mathrm{T} 25$, the other treatments were combinations of both stimulatory methods. However, in the NTP they were remarkably stimulated by $\mathrm{T} 9$ and $\mathrm{T} 18$, with a synergistic effect of the two methods applied.

The MFW reveals significant differences $(\mathrm{p} \leq 0.05)$ in 13 experienced treatment: T5-T8, T20-T26, T28 and T29, of which ten were found to be dose combinations of X-rays and BB-16. At the same time, the yield per plant (YPP) was characterized by a response in line with the values of stimulation observed in the main components of performance. The higher values of stimulation were reached in this indicator, due to the synergistic effect achieved with the combined treatments: T9, T23-24, T28-29.

The results reported in the international literature are limited and refer only to the synergistic effect of several doses of X-rays or gamma and five plant growth hormones, to evaluate the response of plants during development [3]; although there are references related to the combined effect of natural BB-16 and stimulants like Fitomas-E, which showed a synergistic effect on the growth and yield of plants [18].

Apparently stimulating synergistic effect may be related, on the one hand, with hormesis by low doses of ionizing radiation that occurs with changes in the interior of the membranes do not affect seed germination and cause induced activation various enzymes that lead to the formation of physiologically active substances, such as peroxides that at low concentrations cause the activation of cell division, together with the formation in cells of important organelles such as mitochondria and chloroplasts; and increased conversion of reserve substances in comparable products, favoring the formation, growth and yield of plants [31].

Moreover, brassinosteroids also possess the ability to accelerate growth and maturation of plants; also induced brassinosteroids effects can not be considered in isolation, since these compounds interact with other endogenous plant growth regulators and are very sensitive to environmental signals, particularly with the quality of solar irradiation, typical response of other plant hormones [32].

A theoretical analysis of the subject suggests that both X-rays as brassinosteroids significantly increase the RNA and DNA polymerases, RNA synthesis and DNA and proteins. Under the influence of both stimulants, changes in enzyme activities appear to affect the metabolism of nucleic acids, so that the levels of RNA, DNA and protein accumulated in the tissue increases during growth [33, 34].

Confirmation of the synergistic effect of $\mathrm{X}$ and BB-16 rays on plant yield, its components, indicated the need for optimizing the doses and concentrations used in both treatments, which was possible by using the statistical technique of surface response [35]. This allowed us to determine the mathematical model (quadratic function) that best fits the relationship between these stimulating agents and graphically observe the behavior of the dependent variable, in relation to the treatment regimens applied (Figure 1).

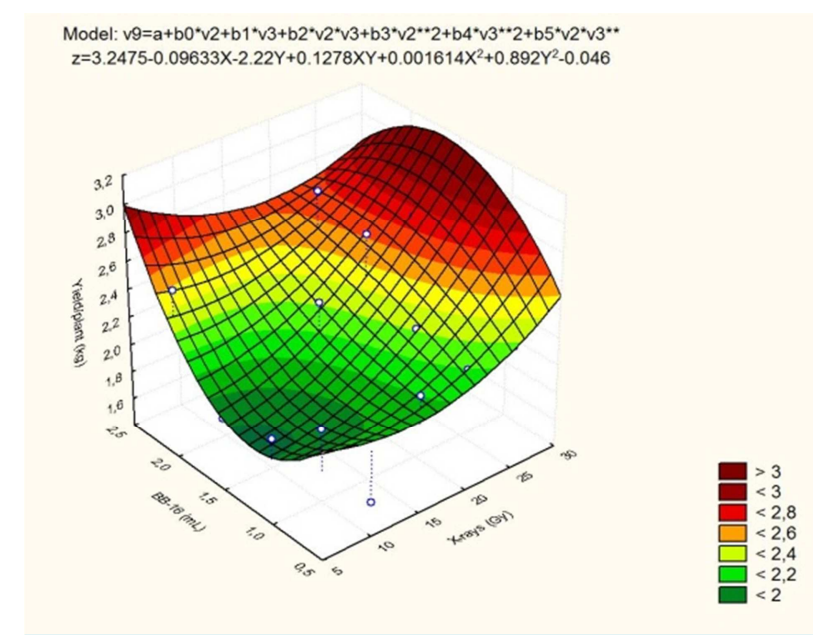

Figure 1. Response surface to obtain optimal values of $X$-ray dose and concentration of BB-16, increasing yield per plant.

The results showed that the optimal combination demonstrated for the dose of 30 Gy ( $X$ rays) and the concentration of $2.0 \mathrm{mg} . \mathrm{L}^{-1}$ (BB-16), increasing the yield of $2.99 \mathrm{Kg}$ per plant. These treatment regimens optimized confirm the existence of synergistic effect.

This behavior also suggests the possibility that plants from these combination treatments could express better response under stress, showing the important role of cell membranes in the plant tolerance to any environmental stressing factor.

Therefore, the observed response could be very important from a practical point of view, for technical agriculture, it would bring significant advantages in increasing agricultural yields.

Conclusion

Exposure of dry tomato seeds to low doses of X-rays (20 and 25 Gy) significantly increased mean fruit weight, fruit 
yield per truss, number of truss per plant and fruit yield per area compared to unexposed seeds. Likewise, BB-16 applied by spray to plant leaves during blooming period showed greater number of fruit per truss for $0.5 ; 1 ; 1.5$ and $2.0 \mathrm{mg} . \mathrm{L}^{-1}$ and the number of truss per plant for $0.5 \mathrm{mg} . \mathrm{L}^{-1}$ while the mean fruit weight and fruit yield per plant for $2.0 \mathrm{mg} . \mathrm{L}^{-1}$ treated plants compared to the control. Also, the combined treatment of low doses of X-rays and BB-16 revealed the synergistic effect particularly for $30 \mathrm{~Gy}$ and $2.0 \mathrm{mg} . \mathrm{L}^{-1}$ confirms the existing synergy between low doses of X-rays and brassinosteroid (Biobras-16).

\section{References}

[1] T.D. Luckey, "Hormesis with ionizing radiation", Boca Raton Florida: CRC Press, 1980.

[2] C. Arena, V. De Micco, E. Macaeva and R. Quintens, "Space radiation effects on plant and mammalian cells", Acta Astronautica, 2014, vol. 1, pp. 419-431.

[3] V. Kumar, and D. Kumar, "Synergistic effect of the combined treatment with ray $\mathrm{X}$ and phytohormones in tomato", Indian Journal of Agricultural Sciences, 1987, vol. 58, no.4, pp. 313-314.

[4] J-X. Cui; Y.-H. Zhou, J.-G Ding, X.-J Xia, K.A.I. Shi, S.-C. Chen, T. Asami, Z. Chen and J.-Q Yu, "Role of nitric oxide in hydrogen peroxide-dependent induction of abiotic stress tolerance by brassinosteroids in cucumber". Plant Cell Environ. 2011, vol. 34, pp. 347-358.

[5] C. J. Yang, C. Zhang, Y. N. Lu, J. Q. Jiny and X.L. Wang, “ The mechanisms of Brassinosteroids' action: from Signal Transduction to plant development”, Molecular Plant, 2011, vol. 4 , no. 4 , pp. 588-600.

[6] M. Núñez, Y. Reyes, L. Rosabal and L. Martínez, "Reseña bibliográfica. Análogos espirostánicos de brasinoesteroides y sus potencialidades de uso en la agricultura". Cultivos Tropicales, 2014, vol. 35, no. 2, pp. 34-42.

[7] A. Hernández, M. Osvaldo, M. Morales and A. Cabrera, "Correlación de la nueva versión de clasificación genética de los suelos de Cuba con las clasificaciones internacionales y nacionales: Una herramienta útil para la investigación, docencia y producción agropecuaria". Instituto Nacional de Ciencias Agrícolas, 2005.

[8] A. Rodríguez, N. Companioni, E. Peña, F. Cañet, J. Fresneda, J. Estrada, and R. Rey, "Manual Técnico para Organopónicos, Huertos Intensivos y Organoponía Semiprotegida”, 2007.

[9] J. Yandell, "Practical Data Analysis for Designed Experiments", London, Chapman and Hall Press. 1997.

[10] M. Melki y D. Sallami, "Studies the Effects of Low Dose of Gamma Rays on the Behaviour of Chickpea under Various Conditions". Pakistan Journal of Biological Sciences. 2008, vol.11, pp.2326-2330.

[11] A. Bovi, J. Valter, T. Neto, "Use of low doses of 60 Co gamma radiation on carrot seeds and their effects on plant growth and yield". IX International Symposium on Timing of Field Production in Vegetable Crops. ISHS Acta Horticulture. 2004, pp. 607.
[12] L. G. Iglesias, L. R. Sánchez, Y. Tivo, M. Luna, N. Flores, J. C. Noa, C. Ruiz, J. L. Moreno, "Efecto de radiaciones gamma en Abies religiosa (Kunth) Schltd". et Cham Revista Chapingo. Serie Ciencias Forestales y del Ambiente. 2010, vol. 16, no. 1, pp. 5-12.

[13] A. Álvarez, R. Ramírez, L. Chávez, Y. Camejo, L. Licea, E. Porras, and B. García, "Efecto del tratamiento de semillas con láser de baja potencia, sobre el crecimiento y rendimiento en plantas de tomate (Solanum lycopersicum, L.)”. ITEA. 2011, vol. 107, no. 3, pp.1-10.

[14] A. Álvarez, R. Ramírez, L. Chávez and Y. Camejo, "Efecto del tratamiento de semillas con radiación láser de baja potencia en un híbrido de tomate (Solanum lycopersicum, L.)". Revista Granma Ciencia. 2011, vol. 15, no. 2.

[15] V. De Micco, C. Arena, D. Pignalosa, and M. Durante, "Effects of sparsely and densely ionizing radiation on plants", Radiat. Environ. Biophys. 2011, vol. 50, pp. 1-19.

[16] J. Ruiz, E. Terry, T. Tejeda and M. M. Díaz, "Aplicación de bioproductos a la producción ecológica de tomate". Cultivos Tropicales. 2009, vol. 30, no. 3, p. 60-64.

[17] A. Alarcón, P. Barreiro M. Godefoy and T. Boicet "Efecto del Biobras-16 en algunos indicadores del crecimiento y rendimiento del tomate, variedad "Campbell-28". Revista Granma Ciencia, 2011, vol. 15, no. 2.

[18] A. Alarcón, P. Barreiro and S. Díaz, "Efecto del Biobras-16 y el Fitomas-E en algunos indicadores del crecimiento y el rendimiento del tomate (Solanum Lycopersicum, Lin) variedad "Vyta". Revista Granma Ciencia. 2012, vol. 16, no. 1.

[19] L. González, M. Núñez, C. Robaina, M. C Jiménez and J. Pérez, "Efecto del Biobras-16 en algunos indicadores agronómicos del tabaco, variedad Sancti Spíritus-96”. Centro Agrícola. 2005, vol. 32 , no. 1 .

[20] B. Torres, A. Espinosa, M. Mendosa, J. L. Rodríguez, M.B. Irizar and J.S. Castellano, "Efecto de brasinoesteroides en híbridos de maíz androestériles y fértiles". Agronomía Mesoamericana. 2007, vol. 18, no. 2, pp. 155-162.

[21] TW. Kim, M. Michniewicz, DC. Bergmann and ZY. Wang, "Bassinosteroid regulates stomatal development by GSK3-mediated inhibition of a MAPK pathway". Nature. 2012, vol. 482, pp. 419-423.

[22] X. Kong, J. Pan, G. Cai and D. Li, "Recent insights into brassinosteroid signaling in plants: its dual control of plant immunity and stomatal development", Mol Plant, 2012, vol.5, pp. 1179-1181.

[23] D. Holá, "Brassinosteroids and photosynthesis. In: Hayat S, Ahmad A, editors. Brassinosteroids: a class of plant hormone", Dordrecht-Heidelberg-London New York: Springer Science+Business Media B.V. 2011, pp. 143-92.

[24] H. Guo, L. Li, M. Aluru, S Aluru and Y. Yin, "Mechanisms and networks for brassinosteroid regulated gene expression". Curr Opin Plant Biol. 2013, vol. 16, pp.545-53.

[25] J.Y. Zhu, J. Sae-Seaw and Z.Y. Wang, "Brassinosteroid signaling". Development, 2013, vol.140, pp.1615-20.

[26] E. Oh, J.Y. Zhu and Z.Y Wang, "Interaction between BZR1 and PIF4 integrates brassinosteroid and environmental responses". Nature Cell Biol. 2012, vol.14, pp. 802-11. 
[27] D. Coll, "Novedades acerca del mecanismo de reconicimiento y trasducción de la señal brasinoesteroide". Revista CENIC, Ciencias Biológicas. 2006, vol. 37, no.2.

[28] K. Caesar, K. Elgass, Z. Chen, P. Huppenberger, J. Witthöft, F. Schleifenbaum, M. R. Blatt, C. Oecking and K. Harter, "A fast brassinolide-regulated response pathway in the plasma membrane of Arabidopsis thaliana". Plant Journal. 2011, vol. 66, pp. 528-540.

[29] L. Xie, C. Yang and X. Wang, "Brassinosteroids can regulate cellulose biosynthesis by controlling the expression of CESA genes in Arabidopsis". Journal of Experimental Botany. 2011, vol. 62, pp. 4495-4506.

[30] C. V Koka, R. E Cerny, R. G. Gardner, T. Noguchi, S. Fujioka, S. Takatsuto and S. Yoshida, "Clouse, S. D. A putative role for the tomato genes DUMPY and CURL-3 in brassinosteroid biosynthesis and response. Plant Physiology. 2000, vol. 122.

[31] A. Geraskin, G. Dikarev, B. Nesterov, and S. Dikareva, "Regularities of cytogenetic effects induced by low doses of ionizing radiation and other technogenous pollutants. In: Proceedings of regional contest of research proposals in natural sciences”. Kaluga. 2001, vol. 2, pp. 318-332.

[32] M. Barbafieri, and E. Tassi, "Brassinosteroids for phytoremediation application", Springer, Netherlands, Dordrecht Heidelberg London New York. 2011, pp. 403-437.

[33] M. Esnault, F. Legue, and C. Chenal, "Ionizing radiation: advances in plant response". Environ. Exp. Bot. 2010, vol.68, pp. 231-237.

[34] S. P. Choudhary, Y.-Q Yu, K. Yamaguchi-Shinozaki, K. Shinozaki, and L-S. Tran, "Benefits of brassinosteroid cross talk". Trends Plant Sci. 2012, vol. 17, pp. 594-605.

[35] P. Box, and B. Wilson, "On the Experimental Attainment of Optimum Conditions (with discussion)". Journal of the Royal Statistical Society Series. 1951, vol. 13, no.1, pp. 1-45. 